\title{
Effect of over tree cooling irrigation on 'Bosc' pear orchards microclimate
}

\author{
Lakatos, L. ${ }^{1}$, Sun, Z. ${ }^{2}$, Zhang, J. ${ }^{3}$, Szabó, Z. ${ }^{4}$, Soltész, M. ${ }^{4} \&$ Nyéki, J. ${ }^{4}$ \\ ${ }^{1}$ University of Debrecen, Centre of Agricultural and Applied Economic Sciences, Department of Agricultural \\ Engeneering H-4032 Debrecen, Böszörményi 138, Hungary, lakatos@agr.unideb.hu \\ ${ }^{2}$ Inst. of Environment and Development in Agriculture (IEDA), Chinese Academy of Agricultural Sciences (CAAS), \\ No. 12, Zhong-guan-cun South Street Beijing 100081 P.R. China \\ ${ }^{3}$ College of Horticulture Shandong Agriculture University, Taian, Shandong Province 271018 P.R.China \\ ${ }^{4}$ University of Debrecen, Institute of Horticulture, H-4032 Debrecen, Böszörményi 138, Hungary
}

\begin{abstract}
Irrigation in some countries is a horticultural practice mainly used only to supply water. At the same time the use of microsprinklers have a powerful influence on the changes of temperature in orchards. When the air's temperature is high (about $20{ }^{\circ} \mathrm{C}$ or higher) the evaporative cooling irrigation significantly decreases the plants' surface temperature and air temperature. The cooling effect is stronger when the air is dryer. By using cooling irrigation regularly, canopy temperature can be decreased so that the beginning of blooming can be delayed. Also if the blooming is early and frost probability is high, serious damages can happen in orchards. The beneficial effect of cooling irrigation is the temperature reduction and frost protection. In March 2010, one month earlier than the expected blooming an irrigation system was established to produce anti-frost treatment and regulate the micro-climate of a Bosc pear orchard which belongs to the University of Debrecen (Hungary). The objective of sprinklers was to cool the air by increasing water evaporation and relative humidity. The position of the micro-sprinklers was planned in three levels (around the tree trunks, a few $\mathrm{cm}$ near to the soil surface, in the crown region and above the crown, a half meter higher). The results showed that the water sprayed in the orchard by micro-jets influenced decisively the temperature of the plantation. At higher temperatures (around $20^{\circ} \mathrm{C}$ ), the drop of temperature may attain $5-7{ }^{\circ} \mathrm{C}$. A low relative humidity of the air may increase the relative effect. When water was applied at intervals of 15 minutes for ten times a day from 8 am to 18 pm, the air, flowers and bud's surface temperature could be kept low. At certain days when the temperature was higher than $10{ }^{\circ} \mathrm{C}$, irrigation was used at night time in similar 15 minutes intervals, from $18 \mathrm{pm}$ and $6 \mathrm{am}$. The beginning of bloom could be delayed for more than ten days. The Bosc pear variety blooming dynamics was characterized by a logistic curve in the treated as well as in the control plot. In the treated plot, the curve was steeper than in the control one in spite of the equal temperatures measured in the plots. Under Hungarian climatic conditions, the method was successfully used to delay blooming dates. The main result was the diminution of the frost damage in the spring that assured pears yields.
\end{abstract}

Key words: Evaporative cooling irrigation, microclimate modification, delay of blooming, pear orchard

\section{Introduction}

Micro irrigation is a horticultural practice mainly used to supply water to the orchard. Nevertheless the micro sprayed irrigation has a powerful influence on fruit microclimatic parameters as temperature and air humidity. When the air temperature is high (about $20{ }^{\circ} \mathrm{C}$ or higher) the evaporative cooling irrigation significantly decreases the plant surface temperature. The cooling effect is stronger in that case when the air is dryer. By using the cooling irrigation frequently the temperature of the canopy (both bud surface and ambient air temperature) can be decreased so the speed of physiological processes will be slower and will result in later blooming of fruit trees. In the case of early blooming varieties the probability of climatic frost is high and can cause serious damages in orchards. The cooling irrigations beneficial effect comes forward to the temperature reduction and frost protection.
Below the freezing point the coexistence of water and ice provides for the flowers that the surface temperature remains around $0{ }^{\circ} \mathrm{C}$, while the temperature of the surrounding air falls to even $-8{ }^{\circ} \mathrm{C}$. Frost protective irrigation is a more wide-spread horticultural practice than cooling irrigation but with the use of cooling irrigation the protection against frost could be significantly escalated.

The dynamics of bloom influenced by the seasonal temperature were examined earlier in apple and sour cherry plantations by Lakatos et al. (2006, 2008, 2009). The effect of over-tree sprinkler irrigation on colorization by cooling 'Sensation Red Bartlett' pear were analyzed by Dussi et al. (1997). That authors stated that fruits from cooled trees were more red and less yellow than fruit from noncooled trees, resulting in lower hue values by the middle of the harvestable maturity period in both years of study. Accordingly, cooled fruit should be harvested earlier than noncooled fruit to 
maintain postharvest quality. Differences between cooled and noncooled fruit with respect to hue, surface blush, and rate of firmness loss were more pronounced in a warm season requiring frequent cooling than in a cooler season.

The latest researches on the topic of micro-climate modification in the orchards are trend to analyze the effect of the evaporative cooling irrigation on fruit quality parameters (Iglesias et al., 2002). By using micro jets above the canopy at least two times a day the cover colour of fruit will get better (Iglesias et al., 2005). Furthermore the evaporative cooling irrigation is suitable for improving the anthocyanine content of the fruit as well (Iglesias et al., 2008).

The aim of this research work was to investigate the effects of evaporative cooling irrigation on orchard microclimate parameters. We wanted to know how we can modify the daily distribution of temperature inside the tree canopy. We wanted to analyze the effect of evaporative cooling irrigation on the dynamics of blooming and how many days we can delay the start of blooming at the researched Bosc pear variety.

\section{Materials and methods}

The effect of evaporative cooling irrigation on the blooming dynamics of pear of three irrigated and nonirrigated pear trees was analyzed. The rate of flowering for each tree by observing 100-100 flowers separately, day by day was calculated. We analyzed the effect of micro-spraying on the daily distribution of tree surface temperature on windy nights and days, when the average wind speed was higher than $10 \mathrm{~m} / \mathrm{s}$. We also investigated the effects of evaporative cooling irrigation on those nights when the relative humidity was lower than $75 \%$, the wind speed was lower than $3 \mathrm{~m} / \mathrm{s}$ and the temperature was higher than $10^{\circ} \mathrm{C}$, and on those days when the daytime maximum temperature was higher than $20{ }^{\circ} \mathrm{C}$ and the average wind speed was above $10 \mathrm{~m} / \mathrm{s}$ separately. Below we introduce our research results for this microclimate modification on changes in blooming times.

Experiments were performed on the Experimental Farm of the Debrecen University, Pallag, Hungary. Measurements refer to a pear plantation with a $5 \times 3 \mathrm{~m}$ planting design and trained to open center system. The pear variety was "Bosc Kobak", planted in 1999.

A special station equipped with thermometers performed measurements with high sensitivity platinum sensors mounted on the branches of the trees near to the buds. The sensors were distributed in the crown at five points, in the center and on the four cardinal directions on the periphery. The sampling time was 10 minutes for each.

The dynamics of bloom were studied according to the system described by Nyéki (1980, 1989, 1990, 2002).

Experiments started in March 2010. Irrigation system was established for the purpose of producing anti-frost treatments and regulating the micro-climate. The role of sprinklers was primarily the prevention of frost damage, contrarily in the present program the goal was to cool the air by increasing evaporation and relative humidity

The treatment began nearly one month prior to blooming. The position of the micro-sprinklers was planned at three levels: around the trunks, a few $\mathrm{cm}$ above to the soil surface, in the crown region and one half meter above the crown.

The program started the sprinklers every 60 minutes for 15 minutes, water was applied at intervals of 15 minutes for ten times a day from 8 am to $18 \mathrm{pm}$. The cooling effect was uniform in the whole space of the crown. The effects of the various levels were not observed immediately, because the evaporation was not intense during this period, and the cooling activity was extended to the entire crown. The greatest effect was due to contact-evaporation on the wet surfaces. Measurements were made to register the three levels together.

\section{Results and discussion}

The evaporative cooling irrigation is a useful method for fruit colorization and for blooming delay. But the over-tree micro sprinkle irrigation has a dangerous effect on plant protection, especially in those regions where the climate is not so dry. Funguses, bacteria spread faster and cause different plant diseases if the air humidity around the tree is constantly high. We should analyse economically the cost of irrigation, risk of plant disease, spraying cost and the advantage of higher fruit quality (better fruit colour, higher sugar content).The efficiency of evaporative cooling irrigation is high in those areas where the temperature and wind speed is high, the air humidity is low. At humid climatic circumstances, where the annual amount of precipitation higher than $600 \mathrm{~mm}$ it is not worse to use it.

During one month period, the temperature of the crown space of the sprinkled trees was $1.5-2.0^{\circ} \mathrm{C}$ lower than in the non-cooled check (Figure 1). Around noon, the difference was even $3{ }^{\circ} \mathrm{C}$. The smallest difference was in the early morning hours: $0.5-1.0^{\circ} \mathrm{C}$.

Although at night time there was no actual solar radiation for an intensive evaporation because of the high wind speed the process was working properly on those nights when the

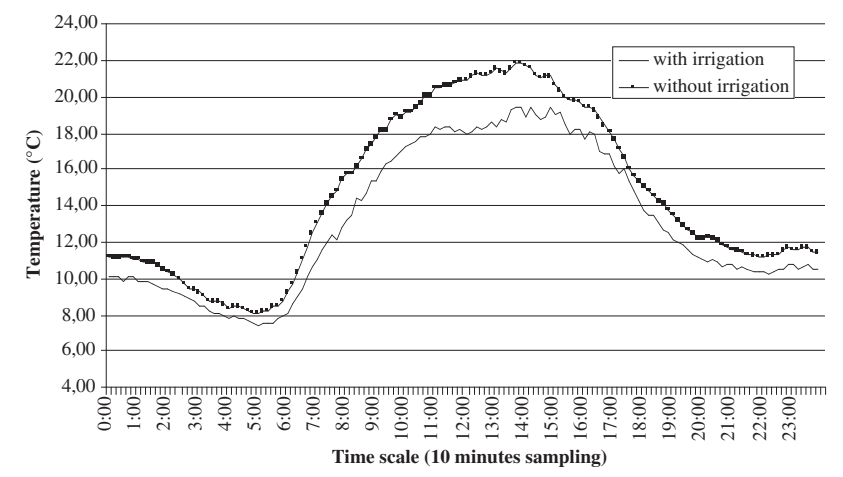

Figure 1. Mean daily temperature in the pear plantation with and without irrigation between March 15 and April 15, 2010 


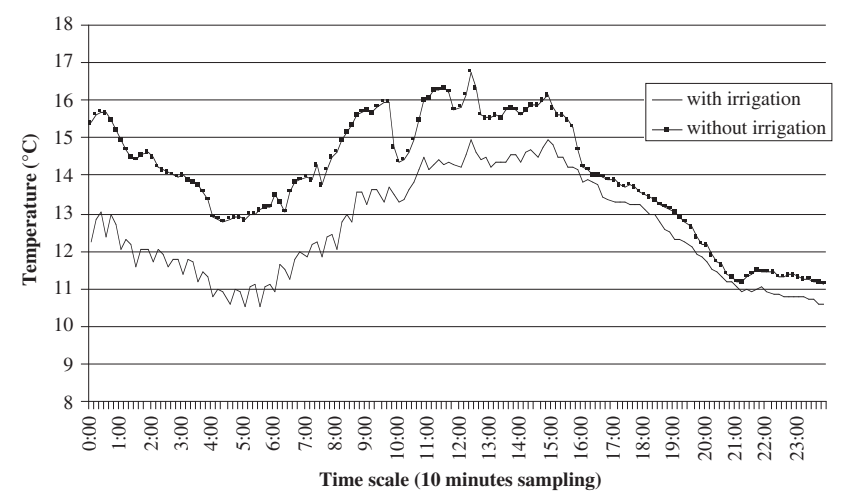

Figure 2. Effect of irrigation those days when the night temperature $(\mathrm{T}>10$ ${ }^{\circ} \mathrm{C}$ ) and wind speed (Vaverage $>10 \mathrm{~m} / \mathrm{s}$ ) was high.between March 15 and May 15, 2010

temperature was above $10{ }^{\circ} \mathrm{C}$ and the average wind speed of the nights was higher than $10 \mathrm{~m} / \mathrm{s}$ (Figure 2.). The surface temperature at the irrigated trees was $3-3,5{ }^{\circ} \mathrm{C}$ lower than non-irrigated ones thanks to the relatively high temperature and wind speed. At low temperatures and doldrums the evaporation is less intense.

It is well known that those days when the wind speed is lower than $3 \mathrm{~m} / \mathrm{s}$ the evaporation is not so intensive because the saturated air mass can slowly flow from the wet surface. The high temperature is suitable for intensive evaporation because the speed of water molecule is higher so its bigger kinetic energy helps the molecule to come out from the water surface easily. Those days when the temperature attained at least $20{ }^{\circ} \mathrm{C}$ at daytime the effect of irrigation on the daily distribution of temperature was intense. On the basis of low wind speed and high temperature it can be stated, that the highest difference between the irrigated and non-irrigated pear plantation can reach $4{ }^{\circ} \mathrm{C}$ at noon (Figure 3 ).

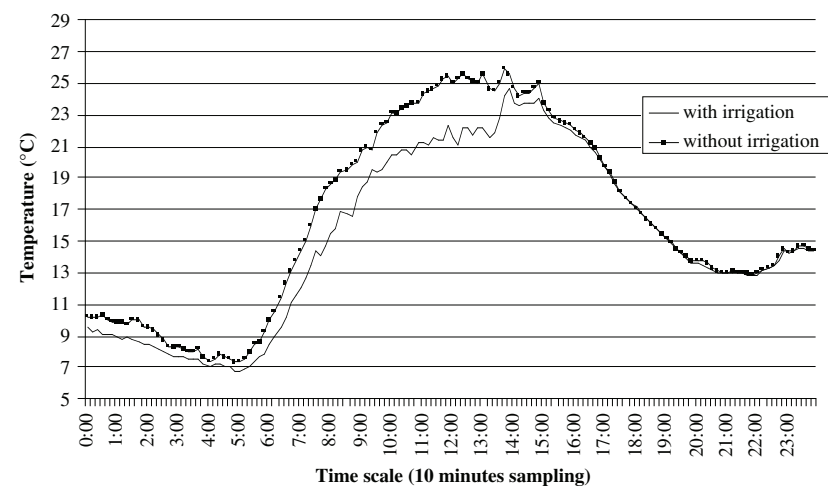

Figure 3. Irrigation. effect on the daily distribution of temperature those days when the wind speed was lower than $3 \mathrm{~m} / \mathrm{s}$ and temperature was higher than $20^{\circ} \mathrm{C}$ - from March 15 to May 15, 2010.

Not only was the high wind speed able to improve the intensity of evaporation but the relatively low air humidity as well. In lower air humidity cases the unsaturated ambient air can absorb many water molecules easily. So the speed of water molecule is higher in those cases when the relative humidity of the air is low. We analyzed separately those nights when the air humidity is not so high (less than $75 \%$ ) in that

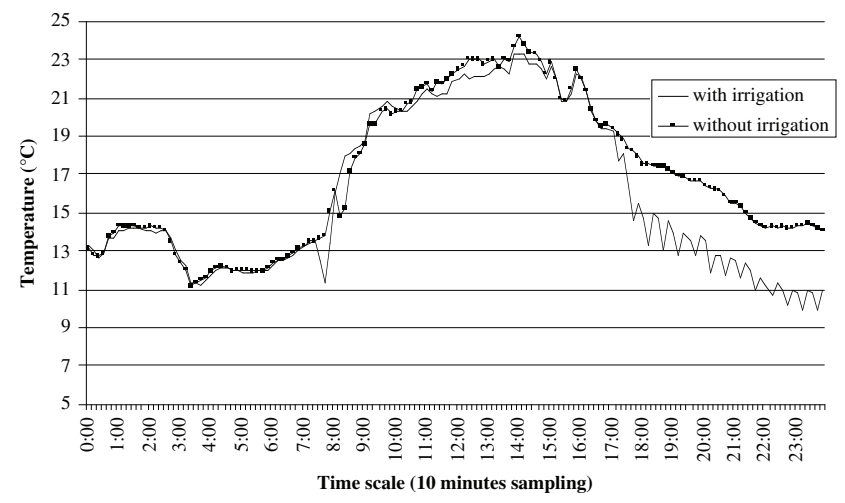

Figure 4. The effect of night time irrigation on the temperature of the pear plantation on the day when the air humidity was below $75 \%$ 2nd of May, 201

nights there were suitable circumstances for evaporation. The highest difference in temperature between the irrigated and non-irrigated pear plantation can reach $3,5^{\circ} \mathrm{C}$ at midnight (Figure 4).

The most conspicuous effect was experienced on those days when the maximum temperature was above $20^{\circ} \mathrm{C}$ and at the same time there was an intensive solar radiation and the wind speed was higher than $10 \mathrm{~m} / \mathrm{s}$, at daytime the irrigated buds were $6-7{ }^{\circ} \mathrm{C}$ cooler than the non-irrigated ones. (Figure 5). If during the research period there had been same weather circumstances as mentioned above several times, the bloom delaying effects of irrigation would had been more efficient.

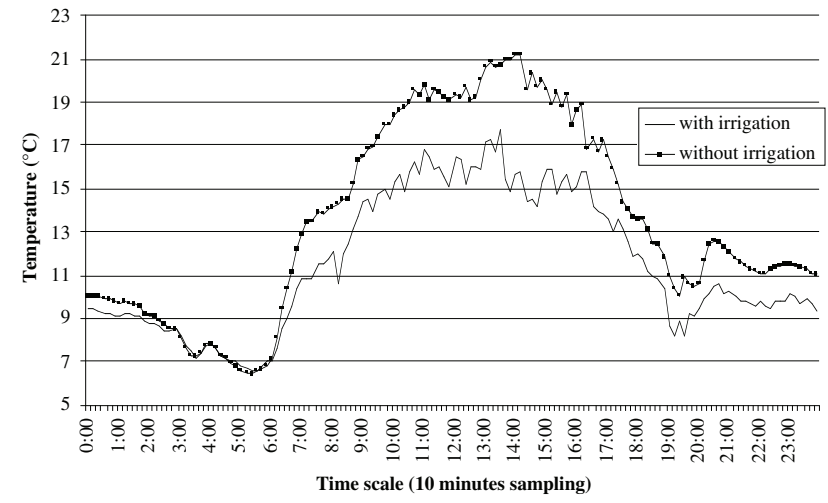

Figure 5. The effect of daytime irrigation on the daily distribution of temperature in pear plantation on a windy day when the average wind speed was higher than $10 \mathrm{~m} / \mathrm{s}$. 29th of April 200

On warm days, when the maximum temperature reached $20{ }^{\circ} \mathrm{C}$, there was an intensive solar radiation and low wind speed-less than $3 \mathrm{~m} / \mathrm{s}$ - and at the same time the relative humidity of the air was less than $50 \%$ at noon, the daily distribution of temperature showed intensive fluctuation (Figure 6). By usage of micro sprinklers the bud surface showed a decreasing of relatively high temperature (2$2,5^{\circ} \mathrm{C}$ ) within short intervals.

Irrigation not only lowered the temperature when it was below $10{ }^{\circ} \mathrm{C}$ but also moderated its fluctuation. On those days, when the sky was cloudy and the temperature was low, we could not find significant differences between irrigated and non-irrigated trees' surface temperature. Irrigation 


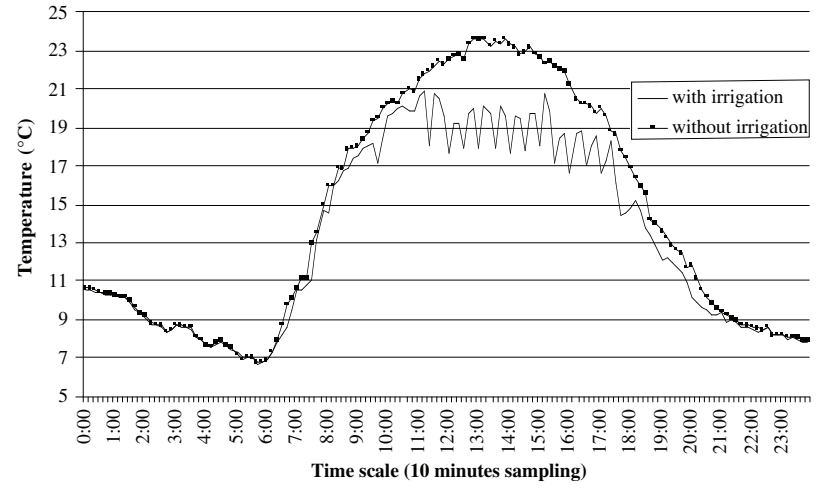

Figure 6. The effect of daytime irrigation on the daily distribution of temperature on the day when the wind speed was lower than $3 \mathrm{~m} / \mathrm{s}$, and the relative humidity less than $50 \%$ at noon- in pear plantation. 23rd of April 201.

diminished the process of warming up and cooling down, thus the risk of heat-stress and sunburn can be reduced.

The retarding effect on blooming by cooling irrigation was measured on three selected trees and as a control group on three dry trees. Non-irrigated trees started blooming at April 14-15, whereas the irrigated trees by 9-10 days later. In Figure 7, the rising angle of the sigmoid-curve was less steep. The time between start of bloom and full bloom lasted 17 days instead of 14 days in the check. The slowing down of the dynamics lasted during the whole blooming period. The dry check finished bloom at May 2 whereas the irrigated at May 14, but the whole blooming period was prolonged by 3 days.

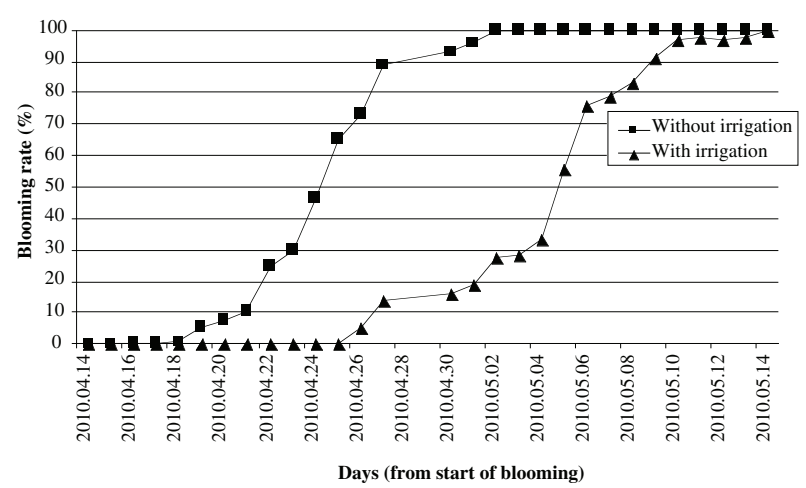

Figure 7. The effect of irrigation on the blooming dynamic of pear. Between April 14 and May 14, 2010

\section{Conclusions}

The micro-sprinkler irrigation is a suitable method for modifying microclimate in orchards (Dussi et al., 1997). The evaporative cooling effect of the irrigation mainly depends on weather circumstances. When the temperature is higher than $10{ }^{\circ} \mathrm{C}$ there is a significant evaporative cooling effect. If the wind speed is less than $3 \mathrm{~m} / \mathrm{s}$ the evaporation is not so intensive the cooling effect is slower and not so efficient than in those cases when the wind speed is higher than $10 \mathrm{~m} / \mathrm{s}$.
On windy days in spring time the intensity of evaporative cooling irrigation is $1,5-2{ }^{\circ} \mathrm{C}$ higher than on those days when the wind speed is below $3 \mathrm{~m} / \mathrm{s}$. The relative humidity of the air is also important in the evaporation. On those days when the relative humidity was about $50 \%$ at noon the evaporative cooling effects' intensity was $1-1,5^{\circ} \mathrm{C}$ higher than on those days when the humidity was above $75 \%$ at early afternoon. The evaporative cooling irrigation was a useful procedure for delaying the start of blooming of Bosc pear variety. The time delaying can reach 9-10 days. By this method, frost damage probability can be decreased by more than $70 \%$, because climatically the frost occurrence at this time of the year is less by $70 \%$ at least.

\section{Acknowledgement}

This study is funded by TECH_08-A3/2-2008-0373 and TECH_08-A4/2-2008-0138 projects.

\section{References}

Dussi, C., D. Sugar, T. Righetti \& A. Azarenko (1997): Effects of cooling by overtree sprinkler irrigation on fruit color and firmness in 'Sensation' Red Bartlett pear. HortTechnology, 7: 55-57.

Iglesias, J. Salvia, L. Torguet \& C. Cabús (2002): Orchard cooling with overtree microspinkler irrigation to improve fruit colour and quality of 'Topred Delicious' apples, Sci. Hortic., 93: 39-51.

Iglesias I., Salvia J., Torguet L. \& Montserrat R. (2005): The evaporative cooling effects of overtree microsprinkler irrigation on 'Mondial Gala' apples. Scientia Horticulturae,103: 267-287.

Iglesias I., Echeverría G. \& Soria Y. (2008): Differences in fruit colour development, anthocyanin content, fruit quality and consumer acceptability of eight 'Gala' apple strains Scientia Horticulturae, 119: 32-40.

Lakatos L., Szabó T., Szabó Z., Soltész M., Nyéki J. (2009): Relation of sour cherry blooming dynamics and meteorological variables. International Journal of Horticultural Science, 15 (4): $17-23$.

Lakatos, L., Szabó, T., Racskó, J., Soltész, M., Szabó, Z., Nagy, J. \& Nyéki, J. (2006): Effects of weather characteristics on blooming dates ina $\mathrm{n}$ aple gene bank plantation between 1984 and 2001. International Journal of Horticultural Science, 12 (2): 37-44.

Lakatos, L., Szabó, T., Soltész, M., Sun, Z., Wang, Y., Szabó, Z. \& Nyéki, J. (2008): Időjárási változók hatása a meggy virágzástarta-mának alakulására. „Klíma-21” Füzetek, (53): 60-67.

Nyéki, J. (1980): Gyümölcsfajták virágzásbiológiája és termékenyülése. Mezőgazdasági Kiadó, Budapest, 334. p.

Nyéki, J. (1989): Csonthéjas gyümölcsűek virágzása és termékenyülése. MTA, Budapest. Doktori értekezés (kézirat), 288-110.

Nyéki, J. (1990): A gyümölcstermő növények virágzása, megporzása és termékenyülése. [In: Gyuró, F. Gyümölcstermesztés] Mezőgazdasági Kiadó, Budapest, 61-90.

Nyéki, J. (2002): Gyümölcstermő növények virágzása és termékenyülése, ültetvények fajtatársítása. Egyetemi jegyzet. Debrecen. 68 . 